\title{
О ПОЧИТАНИИ СВ. ЕП. ВАСИЛЕЯ В РАННЕСРЕДНЕВЕКОВОМ ХЕРСОНЕ
}

\author{
М. В. Фомин
}

Фомін М. В. Про шанування св. спископа Василя в ранньосередньовічному Херсоні. Св. єП. Василей був першим із семи єпископів херсонських. 3 його шануванням пов'язана низка пам'ятників на мапі Херсонеса-Херсона. В першу чергу це комплекс Західної базиліки, який почав формуватися навколо місця поховання святого. Іншим пам'ятником може бути склеп «на землі Н. І. Тура», котрий був перебудований у меморіальну церкву на спогад про «диво воскресіння хлопчика», описаного в Житії. Ще одним пам'ятником може бути церква, що була побудована в центрі міста над місцем убивства святого і відома за джерелами як церква св. Василя.

Ключові слова: мартирій; склеп; християнство; культ святих; некрополь; єпископи херсонські.

Фомин М. В. О почитании св. еп. Василея в раннесредневековом Херсоне. Св. еп. Василей был первым из семи епископов херсонских. С его почитанием связан ряд памятников на карте Херсонеса-Херсона. В первую очередь это комплекс Западной базилики, который начал формироваться вокруг места погребения святого. Другим памятником может быть склеп «на земле Н. И. Тура», который был перестроен в мемориальную церквушку в воспоминание о «чуде воскрешения мальчика», описанного в Житии. Еще одним памятником может быть церковь, поставленная в центре города над местом убиения святого и известная по источникам как церковь св. Василия.

Ключевые слова: мартирий; склеп; христианство; культ святых; некрополь; епископы херсонские.

Fomin M. $\boldsymbol{V}$. About the Veneration of St. Bishop Basil in the Early Medieval Cherson. Saint bishop Basil was the first of the seven bishops of Chersonesus. A number of monuments on the map of Chersonesus-Cherson are connected with the honour of his memory. The complex of the Western Basilica which was built around the site of the burial of the saint is the first of them. The second one could be the crypt "on the N. Tur land" reconstructed later into the memorial church as a remembrance of the "miracle of the resurrection of the boy" described in the Lives. The church known by sources as the Church of Saint Basil built on the site of the saint assassination could be another memorial of the saint.

Keywords: martirium; Christianity; crypt; saints worship; necropolis; bishops of Chersonesus.

Процесс превращения античного города в раннесредневековый традиционно привлекает к себе значительное внимание со стороны исследователей ${ }^{1}$. Одним из ключевых этапов такой трансформации, охватившей фактически все направления жизни горожан, принято считать идеологические изменения, связанные с кризисом античного мировоззрения и распространением христианства.

Несмотря на значительное количество письменных источников как христианского, так и нехристианского происхождения, вопрос распространения новой религии на просторах поздней Римской империи остается до конца нерешенным. Чрезмерно критический или, наоборот, излишне доверительный подход к прочтению текстов не позволяет восстановить реальную картину.

Во многом компенсировать это может привлечение памятников материальной культуры. Но здесь возникают свои трудности. Слабая исследованность позднеантичных раннехристианских центров не позволяет широко использовать археологический материал, на что неоднократно обращали внимание исследователи².

В этой связи Херсонес Таврический является уникальным комплексом: город расположен вне современной городской застройки, на его территории более ста лет продолжаются системные археологические раскопки; накопленный материал позволяет проследить многие процессы, происходившие в этом позднеантичном-ранневизантийском центре на окраине Империи. Одним из интереснейших остается вопрос формирования раннехристианского мировоззрения среди жителей города. Ключевым моментом этого процесса стало зарождение культа местночтимых святых как отражения Церковной истории города. 
Вопрос проникновения, распространения и утверждения христианства в Херсонесе-Херсоне, несмотря на более чем столетнее изучение и значительную историографию, сохраняет дискуссионный характер. Большинство специалистов остаются сторонниками версии о поздней дате христианизации города и определяют ее концом IV-V вв. ${ }^{3}$. Однако существует и иная точка зрения, датирующая этот процесс концом III-IV вв. ${ }^{4}$. Единственный письменный источник - Жития епископов херсонских - сохранил рассказ о сложном и длительном, а порой и трагичном процессе становления Церкви в городе

После утверждения христианства в середине - конце IV в. формируется культ первых христиан и почитания мест, связанных с историей становления Церкви в городе ${ }^{6}$. В текстах источников, посвященных истории раннесредневекового Херсона (название Херсонеса Таврического в византийское время), сохранились такие топонимы как «могилы святых» (кладбище в Карантинной балке), «святые ворота» (вероятно, западные ворота) 7 .

Почитание святых епископов Херсонских, крестивших город, становится одним из ключевых моментов в развитии местной Церковной истории. Среди епископов выделяется фигура первого из «Семи святых епископов Херсонских»-св. еп. Василея.

Согласно тексту Жития, он был отправлен в Херсонес епископом иерусалимским Ер-

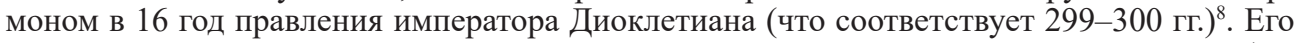
проповедь натолкнулась на яростное сопротивление со стороны язычников - епископ был избит и вынужден был скрываться9.

Вокруг места укрытия св. Василея ведется длительная дискуссия. На сегодняшний день сформулировано несколько предположений о его локализации. Тексты Жития упоминают о некой пещере «Парфенон». Сам термин 'Парфенон' в топографии Херсона присутствует в двух случаях - как место, где укрывался св. Василей, и как район города, где был размещен отряд Феоны, прибывший в город вместе со св. еп. Капитоном.

Херсонесский Парфенон мог быть центром поклонения Деве - Партене, синкретическому божеству, являвшемуся покровителем и защитником городской общины ${ }^{10}$. Об особом отношении к богине Деве сообщают эпиграфические и нумизматические памятники ${ }^{11}$. Значительный интерес представляет упоминание Страбона о том, что «... в городе есть святилище Девы (какого-то божества). В 100 стадиях перед городом находится мыс, названный по имени этого божества Парфением, с храмом божества и его статуей» ${ }^{12}$. Интересную информацию о сакральной пещере сообщает Помпоний Мела: «...город Хенрсонес, основанный по преданию Дианой и особенно известный Нимфейской пещерой, которая находится в городской крепости и посвящена нимфам» ${ }^{13}$.

К поискам пещеры обращались многие ученые. Сегодня можно выделить несколько локализаций. Так, Н. В. Днепровский помещал святилище на мысе Виноградный, в окрестностях современного Севастополя ${ }^{14}$. В свою очередь, А. Ю. Виноградов указывает на восточный мыс Херсонеса как на возможный вариант расположения пещеры, которая могла не сохраниться в результате обрушения части берега ${ }^{15}$.

Главная улица античного Херсонеса вела к восточному мысу, на котором были открыты остатки античного культового комплекса. Исследования М. И. Золотарева и А. В. Буйских обосновали существование здесь двух храмов, один из которых и был посвящен культу богини Девы-Парфены ${ }^{16}$.

Существует и иная точка зрения, увязывающая пещеру «Нимф» или подземное святилище Девы и «Пещерный храм» на главной улице Херсонеса. Впервые такое предположение было отражено в трудах В. В. Латышева и Д. В. Айналова, в этом их поддержал С. А. Беляев ${ }^{17}$.

Само сооружение представляет собой вырубленное в скале углубление сложной формы (на уровне современной поверхности близко к прямоугольнику $8,34 \times 4,65$ м, глубиной около 5,8 м). Внутри просматривается трехконхиниальная апсида. В правой, юго-восточной стене была небольшая овальная ниша $(2,80 \times 1,80$ м) частично заложенная камнем. В нише в западной стене присутствовало еще одно углубление $(1,40-1,80 \times 0,80 \times 1,0$ 1,20 м), которое могло служить гробницей ${ }^{18}$.

Сооружение было открыто и исследовано в 1883-1884 гг. представителями Одесского общества истории и древности ${ }^{19}$. К сожалению, уровень фиксации результатов раскопок был очень низок, что приводит к многочисленным дискуссиям о конструкции и назначении подземного сооружения. 
Во время исследований были обнаружены кости и шесть черепов ${ }^{20}$. Это дало основание полагать, что подземное сооружение могло использоваться в позднее время как мартирий. Сверху, над ним, была возведена мемориальная церковь $(8 \times 5$ м). А. Л. Якобсон выдвинул предположение, что первоначально храм мог иметь центрическую композицию, подобную крестовидным мартириям. Но подрубы в скале над криптой свидетельствуют о прямоугольной форме сооружения ${ }^{21}$.

Дату возникновения подземного сооружения относят ко времени не позднее $\mathrm{V}$ в. $^{22}$. Использование его в качестве мартирия может быть датировано временем не ранее VI-VII вв. ${ }^{23}$.

Учитывая особое отношение в средние века к подземному сооружению на главной улице, есть основания предполагать, что оно и могло быть той самой пещерой «Парфенон», где скрывался св. Василей. О присутствии в этом районе античного храма свидетельствуют находки баз античных известняковых колонн ${ }^{24}$, а также фрагменты скульптуры «кусок мраморного барельефа с женской фигурой без головы (как будто Артемидой), кусочек сидящей фигуры, тоже мраморной, и об Артемиде весьма изрядной работы» ${ }^{25}$.

Изменения в политическом положении города в начале новой эры привели к кризису традиционного полисного мировоззрения. Это проявилось как в поиске новых религиозных направлений, получивших распространение в городе в первые века, так и в утрате значения многих более ранних культов. Возможно к концу III - началу IV вв. культовый комплекс, включавший подземный храм, пришел в упадок и был заброшен. Рядом с этим местом возникли хозяйственные постройки, просуществовавшие до второй четверти IV в. ${ }^{26}$.

Таким образом, одной из наиболее вероятных локализаций пещеры «Парфенон», места, где укрывался св. еп. Василей, может быть подземное сооружение на главной улице. Позднее над ней была сооружена мемориальная церковь, а сама крипта могла использоваться как мартирий.

Другим топосом может быть место убиения святого. Известно, что разъяренные язычники его «влакли по улице, побивая камнями и палками» ${ }^{27}$. Текст Жития указывает, что позднее на месте смерти святого была установлена колонна с крестом ${ }^{28}$. Сегодня существует несколько предположений о том, где это могло произойти. В этой связи значительный интерес представляет один из текстов, описывающих Корсунский поход св. Владимира, принявшего в крещение имя Василий. «Крестился же он в церкви св. Василия, а стоит церковь та в г. Корсуни, посреди града, где собираются корсунцы на торг» ${ }^{29}$. Можно предположить, что в VI-VII вв. на месте колонны с крестом была возведена мемориальная церковь в честь св. еп. Василея, которая стала местом крещения князя Владимира.

В середине XIX в. в центре городища, на агоре, был возведен Владимирский собор. Он накрыл крестообразную церковь, остатки которой сохранились на первом этаже монументального сооружения.

Крестообразная церковь на агоре (известная как № 27) имела стены толщиной более метра, что может быть основанием для предположения, что она имела сводчатое перекрытие и купол. Как отмечал первооткрыватель церкви К. Крузе, в апсиде был устроен высокий «в виде амфитеатра» синтрон, украшенный «мраморными тонкими позолоченными дощечками» ${ }^{30}$. Службы, совершавшиеся в храме, могли собирать значительное количество духовенства и, возможно, иметь мемориальный характер. Богатое убранство, мраморные детали во внутреннем пространстве, мозаичный пол - все это свидетельствует об особом отношении горожан к храму.

Следующим топосом может стать место погребения святого. Согласно агиографическому источнику, епископ был похоронен «вне города на западе близь стен» ${ }^{31}$. Многие современные исследователи связывают с местом погребения св. еп. Василея склеп за античной Западной крепостной стеной, позднее оказавшийся на территории комплекса Западной базилики ${ }^{32}$.

Склеп имел несколько нетрадиционную архитектуру и, вероятно, претерпел перестройку во время возведения над ним мемориального храма «Г» ${ }^{33}$. Арочный свод вел через дромос $\left(1,8 \times 0,85\right.$ м) в погребальную камеру $(2,25 \times 2,25 \times 1,7 \text { м })^{34}$. В отличие от большинства Херсонесских склепов, потолок был выложен полуцилиндрическим сводом из плинфы на розоватом цемянковом растворе. В погребальной камере напротив входа находится лежанка необычно крупных размеров - 1,25 м. Во время исследований, кроме человеческих костей и «костяной точеной застежки», в склепе ничего обнаружено не было ${ }^{35}$. 
Над самим склепом был возведен храм «Г», который первоначально представлял собой часовню, к которой позднее была пристроена небольшая апсида. Таким образом, она трансформировалась в мемориальную церковь.

Во время раскопок храмика была открыта in situ алтарная преграда и мраморный порог. Пол в алтарной части был выложен из каменных плит. Остальная его часть оказалась украшена мозаикой «очень красивого и... древнейшего рисунка» ${ }^{36}$.

Техника и орнамент мозаики были схожи с мозаикой Уваровской базилики, традиционно датируемой VI-VII вв. ${ }^{37}$, однако возведение сооружения определенно может быть отнесено к более раннему времени. Мемориальная часовня, вероятно, была возведена в конце IV - начале V вв. и позднее перестроена в церковь ${ }^{38}$.

Также значительный интерес представляет склеп «на земле Н. И. Тура». Он относиться к числу херсонесских склепов, содержащих полихромную погребальную живопись. Он был открыт в 1894 г., но раскопан лишь в 1912 г. ${ }^{39}$. В плане изначально являлся типичным для подобных сооружений, но позднее был перестроен.

Лежанка, расположенная напротив входа, была углублена до уровня пола, а образованное таким образом пространство было соединено проходом, прорубленным в перемычке. Сам памятник, а также его уникальные росписи неоднократно были объектом обсуждения ${ }^{40}$.

Учитывая особое отношение херсонитов к склепу, перестройку его в подземную церковь, имевшую мемориальные функции говорит о его значительном месте среди раннехристианских памятников города. Существует предположение, увязывающее его с житийным чудом воскрешения мальчика по молитве св. Василея ${ }^{41}$.

Анализ архитектуры склепа позволяет предположить, что в нем совершались периодически Богослужения и даже Литургия. В стене с апсидой присутствуют выступ и ниша, которые, по мнению А. А. Филипова, могли использоваться в качестве престола, на котором совершалась Евхаристия ${ }^{42}$. Подобные литургические устройства неоднократно описывал Ю. Ю. Шевченко ${ }^{43}$.

На это обращает внимание и особенность росписи над нишей. Композиция, состоящая из павлинов, поддерживающих в клювах гирлянду из лавровых веток, построена вокруг изображенного в центре «евхаристического хлеба» ${ }^{44}$. Аналогичные изображения хлеба известны по многим памятникам раннехристианского искусства, в частности, они встречаются в мозаиках Равенны ${ }^{45}$.

Все вышесказанное позволяет констатировать, что почитание св. Василея и мест, связанных с его земной деятельностью, играло значительную роль в становлении Церкви в городе. Распространенная в раннем средневековье традиция станциональных литургий могла иметь место и в Херсонесе. В таком случае, один из вариантов мог иметь отношение к почитанию памяти св. еп. Василия и проходить от места его укрытия на главной улице через агору и место его гибели к месту упокоения святого.

Почитание св. еп. Василея сформировалось в середине - конце IV в. и возможно сохранялось долгое время. Возможно именно в церкви св. Василея мог креститься князь Владимир (в крещении Василий). Таким образом вычерчивается некая преемственность между святым, крестившим Херсонес, и святым, крестившим Русь.

${ }^{1}$ Введение в историю Церкви. Часть 1: Обзор источников по общей истории Церкви: Учебное пособие / Под ред. В. В. Симонова. М., 2012. 752 с.

${ }_{2}^{2}$ Романчук А. И. Исследования Херсонеса - Херсона: Раскопки. Гипотезы. Проблемы: [в 2 ч.]. Ч. 2. Византийский город. Екатеринбург, 2007. С. 16

${ }^{3}$ Мещеряков В. Ф. О времени появления христианства в Херсонесе Таврическом // Актуальные проблемы изучения истории религии и атеизма. Л., 1978. С. 121-144; Зубарь В. М. По поводу датировки христианской росписи склепов из некрополя Херсонеса // Научно-атеистические чтения в музеях. Л., 1988. С. 3-14; Зубарь В. М. Проникновение и утверждение христианства в Херсонесе Таврическом // Византийская Таврика. К., 1991. С. 8-29; Золотарев М. И., Хапаев В. В. Херсонесские святыни. Севастополь, 2002. С. 15-21; Завадская И. А. Христианизация ранневизантийского Херсонеса (IV-VI вв.) // МАИЭТ. 2004. Вып. 10. С. 402-426; Цукерман К. Епископы и гарнизон Херсона в IV веке // МАИЭТ. 1994. Вып. 4. С. 445-456.

${ }^{4}$ Ростовщев М. И. Античная декоративная живопись на юге России. СПб., 1914; Кулаковский Ю. А. Прошлое Тавриды. К., 1914. С. 51-52; Беляев С. А. Христианская топография Херсонеса. Постанов- 
ка вопроса, история изучения и современное положение // Рождественские чтения. Церковные древности. Сборник докладов. М., 1999. С. 256-258; Диатроптов П. Д. Распространение христианства в Херсонесе Таврическом в IV-VI вв.// Античная гражданская община. Межвузовский сборник научных трудов. М., 1986. С. 127-151; Фомин M. B. К вопросу о формировании христианской общины в позднеантичном Херсонесе // Материалы по археологии и истории античного и средневекового Крыма. - 2012. Вып. IV. С. 69-77.

${ }^{5}$ Могаричев Ю. М. Жития епископов Херсонских в контексте истории Херсонеса Тавричесского / Ю. М. Могаричев, А. В. Сазанов, Т. Э. Саргсян, С. Б. Сорочан, А. К. Шапошников // Napteks. Byzantina Ukrainensis. Харьков, 2012.

${ }^{6}$ Фомин М. В. О культе местночтимых святых в ранневизантийском Херсоне // Вісник Харківського національного університету імені В. Н. Караізна. Харків, 2015. № 1145: Серія «Історія». Вип. 50. C. $225-232$.

${ }^{7}$ Сорочан С. Б. Византийский Херсон...

${ }^{8}$ Виноградов А. Ю. «Миновала уже зима языческого безумия...». Церковь и церкви Херсона в IV веке по данным литературных источников и эпиграфики. М., 2010. С. 18.

${ }^{9}$ Виноградов А. Ю. «Миновала уже зима языческого безумия...» Церковь и церкви Херсона в V веке по данным литературных источников и эпиграфики. М., 2010. С. 22.

${ }^{10} \mathrm{O}$ культе Девы см. подробнее: Лапина О. В. Херсонесская Партенос (историографический аспект) // Акра - Нижний Новгород, 2002. С. 70-71; Мещеряков В. Ф. О культе богини Девы в Херсонесе Таврическом // Актуальные проблемы изучения истории религии и атеизма. Л., 1979. С. 104-118.

11 Зубарь В. М. Боги и герои античного Херсонеса. К., 2005.

12 Страбон. География в 17 книгах. М., 1994. С. 301.

13 Помпоний Мела. О положении земли. Кн. 2. Гл. 1. Европейская Скифия. URL: http://annales. info/ant lit/mela/02.htm (дата посещения: 27.04.2016).

${ }_{14}$ Днепровский Н. В. К вопросу о локализации пещерного убежища святого Василия, епископа херсонесского // Материалы по археологии и истории античного и средневекового Крыма. 2008. Вып. I. C. 136-137.

${ }^{15}$ Виноградов А. Ю. «Миновала уже зима языческого безумия...». Церковь и церкви Херсона в IV веке по данным литературных источников и эпиграфики. М., 2010. С. 27.

16 Золотарев М. И., Буйских А. В. Теменос античного Херсонеса. Опыт архитектурной реконструкции // Вестник древней истории. 1994. № 3.

${ }^{17}$ См. подробнее: Днепровский Н. В. К вопросу о локализации пещерного убежища святого Василия, епископа херсонесского // Материалы по археологии и истории античного и средневекового Крыма. 2008. Вып. І. С. 132-133.

18 Сорочан С. Б. Два лика «Пещерного храма» Херсонеса-Херсона // Херсонесский колокол. 2008. C. 344-352.

${ }^{19}$ Отчет императорского ООИД с 14-го ноября 1883 г. по 14-е ноября 1884 г. Одесса, 1885. С. $18-21$.

${ }^{20}$ Отчет императорского ООИД с 14-го ноября 1883 г. по 14-е ноября 1884 г. Одесса, 1885. С. 20.

${ }^{21}$ Сорочан С. Б. Византийский Херсон. Очерки истории культуры. Харьков, 2005. С. 739-743.

${ }^{22}$ Сорочан С. Б. Византийский Херсон. Очерки истории культуры. Харьков, 2005. С. 739-743.

23 Зубарь В. М., Хворостяный А. И. От язычестыва к христианству. К., 2000. С. 93; Сазанов А. B. Погребения в христианских храмах Херсонеса XI - XIV вв. // Херсонес Таврический. У истоков мировых религий: Мат. науч. конф. Севастополь, 2001. С. 46; Фомин М. В. Погребальная традиция и обряд в византийском Херсоне (IV - Х вв.). Харьков, 2011. С. 78.

24 Золотарев М. И. Отчет о раскопках в северо-восточном районе Херсонеса в 1978 г. // Архив Национального заповедника «Херсонес Тавричесский», д. 2051, л. 6, рис. 7-11.

${ }^{25}$ Цит. по Сорочан С. Б. Два лика «Пещерного храма» Херсонеса-Херсона // Херсонесский колокол. 2008. С. 344-352.

26 Золотарев М. И. Отчет о раскопках в северо-восточном районе Херсонеса в 1978 г. // Архив Национального заповедника «Херсонес Тавричесский», д. 2051, л. 3-5, рис. 2-5.

${ }^{27}$ Виноградов А. Ю. «Миновала уже зима языческого безумия...». Церковь и церкви Херсона в IV веке по данным литературных источников и эпиграфики. М., 2010. С. 32-33.

${ }^{28}$ Виноградов А. Ю. «Миновала уже зима языческого безумия...». Церковь и церкви Херсона в IV веке по данным литературных источников и эпиграфики. М., 2010. C. 32-33.

${ }^{29}$ Сорочан С. Б. Жизнь и гибель Херсонеса / С. Б. Сорочан, В. М. Зубарь, Л. В. Марченко. Харьков, 2000. С. 294-295, 298-299; Сорочан С. Б. О церкви св. Василия и архитектурном комплексе большой агоры раннесредневекового Херсона // Софійські читання: Мат. І наук.-пракг. чит. К., 2003. C. 96; Протоиерей Александр Пелин. Топография христианского Херсонеса IV-XIV вв.: Дис. ... канд. богословия. / Московская Духовная Академия. Сергиев Посад, 2001 (рукопись). С. 84-93.

${ }^{30}$ Цит. по Сорочан С. Б. Жизнь и гибель Херсонеса / С. Б. Сорочан, В. М. Зубарь, Л. В. Марченко. Харьков, 2000. С. 552.

${ }^{31}$ Виноградов А. Ю. «Миновала уже зима языческого безумия...». Церковь и церкви Херсона в IV веке по данным литературных источников и эпиграфики. М., 2010. C. 32-33. 
${ }^{32}$ Фомин М. В., Огиенко Е. В., Шевцова А. А. О культовом комплексе Западной базилики в средневековом Херсонесе-Херсоне // Материалы по археологии и истории античного и средневекового Крыма. 2015. Вып. VII. С. 127-152.

${ }_{33}^{33}$ Фомин М. В., Шевиова А. А. О раннехристианских комплексах Херсонеса // Вісник Харківського національного університету імені В. Н. Каразіна. 2013. № 1087: Сер. «Історія». Вип. 47. С. 22-33.

${ }^{34}$ Фомин М. В. О мартирии при Западной базилике Херсонеса // Боспорские исследования. Вып. 10. Симферополь, 2006. С. 132-152.

${ }^{35}$ Косиюшко-Валюжинич К. К. Отчет за 1901 г. // Архив Национального заповедника «Херсонес Тавричесский», д.10, л. 10.

${ }^{36}$ Косиюшко-Валюжинич К. К. Отчет за 1901 г. // Архив Национального заповедника «Херсонес Тавричесский», д. 10, л. 10-13.

${ }^{37}$ Сорочан С. Б. Византийский Херсон. Очерки истории культуры. Харьков, 2005. С. 844.

${ }^{38}$ Сорочан С. Б. Византийский Херсон. Очерки истории культуры. Харьков, 2005. С. 827-851

39 О склепах см. подробнее: Фомин $M$. B. Раннехристианская живопись позднеантичного Херсонеса // Материалы по археологии и истории античного и средневекового Крыма. 2014. Вып. VI. C. 299-390.

40 Фомин М. В., Огиенко Е. В., Шевцова А. А. О культовом комплексе Западной базилики в средневековом Херсонесе-Херсоне // Материалы по археологии и истории античного и средневекового Крыма. Вып. VII. Сб. / Ред.-сост. М. М. Чореф. Севастополь-Тюмень, 2015. С. 127-128.

${ }^{41}$ Фомин М. В. Раннехристианская живопись позднеантичного Херсонеса // Материалы по археологии и истории античного и средневекового Крыма. 2014. Вып. VI. С. 299-390.

42 Филиппов А. Е. Росписи раннехристианских склепов Херсонеса Тавричесского в контексте художественной традиции: синтез с архитектурой, символика, литургическая основа // Очерки по истории христианского Херсонеса / отв. ред. С. А. Беляев. СПб., 2009. С. 58-59.

${ }_{43}$ Шевченко Ю. Ю. К вопросу о методике датировки первохристианских пещерных храмов восточной Европы // Материалы по археологии и истории античного и средневекового Крыма. 2011. Вып. 3. С. 55-147.

${ }_{44}$ Фомин М. В. Раннехристианская живопись позднеантичного Херсонеса // Материалы по археологии и истории античного и средневекового Крыма. 2014. Вып. VI. С. 299-390.

${ }^{45}$ Матвеева Ю. Декоративные ткани в мозаиках Равенны. Семантика и культурно-смысловой контекст. Харьков, 2016. С. 66-70. 